\title{
A study into the reasons for process improvement project failures: results from a pilot survey
}

\begin{abstract}
Purpose

Process improvement initiatives, such as Lean, Six Sigma and Lean Six Sigma, typically have common characteristics which are carried through projects. Whilst a project's performance is an important determinant of the successful implementation of continuous improvement $(\mathrm{CI})$ initiatives, its failure can undermine the impact of any CI initiative on business performance. As a result, an understanding of the reasons of process improvement project failures is crucial. In this paper, the results of a pilot survey highlighting the most common reasons for process improvement project failures is presented.
\end{abstract}

\section{Design/methodology/approach}

This paper presents a pilot survey of 42 Brazilian manufacturing specialists who have been involved in process improvement projects. The participants of this survey were Six Sigma Master Black Belts, Black Belts, Green Belts and Six Sigma champions from manufacturing companies in Brazil. The survey questionnaire was piloted with five experts in the field in order to ensure that the questions were valid and technically sound. 


\section{Findings}

The execution of Six Sigma projects in organisations results in a moderate rate of project failures. These failures can cost organisations several millions of dollars especially within the context of larger organisations. The main reasons for project failure, as cited by the specialists include; resistance to change, lack of commitment and support from top management and incompetent teams.

\section{Research limitations/implications}

The authors report the findings from a pilot survey having a limited sample size. Moreover, the data has been collected from one country and primarily from large manufacturing companies.

\section{Originality/value}

To the best of the authors' knowledge, this is the first empirical study looking into the reasons for process improvement project failures. The authors argue that if the top reasons for such failures are understood, a framework can be developed in the future that can mitigate the chance of project failures during project execution. This could potentially lead to significant savings to the bottom-line of many organisations.

Keywords: Process Improvement Failures Projects Survey Continuous
Improvement

Paper type: Research Paper 


\section{Introduction}

The need for business process improvement has become indispensable to overcoming contemporary challenges and achieving and sustaining competitive advantage (Antony and Gupta, 2018). Various structured continuous improvement approaches, which were originally based on the philosophies and methods of Total Quality Management (TQM), developed into Lean Manufacturing, Six Sigma, and Lean Six Sigma and have become a core strategic element in organizations to improve internal and external process performance and to succeed in competitive markets (Adebanjo, Samaranayake, Mafakheri and Laosirihongthong, 2016; McLean, Antony, Dahlgaard, 2017; Tewari, Mittal and Khanduja, 2017). Today, Business Process Improvement (BPI) initiatives such as Lean and Six Sigma are an integral part of the overall business strategy for many organizations across a range of services and a range of industry sectors (Adebanjo et al., 2016).

Most process improvement initiatives, conducted through projects have common characteristics (Anand, Ward and Tatikonda, 2010; Tkáč and Lyócsa, 2009). Lean projects require an understanding of systems-wide processes and utilize interdisciplinary teams (DeSanctis, Mere, Bevilacqua and Ciarapica, 2018; Stelson, Hille, Eseonu and Doolen, 2017; Wackerbarth, Strawser-Srinath and Conigliaro, 2015). Six Sigma is a project-driven management approach (Bilgen and Sen, 2012; Arumugan, Antony and Linderman, 2014, 2016) which employs structured methods and tools to improve products, services and processes (Arumugan, Antony and Linderman, 2014; Laux, Johnson and Cada, 2015; Tkáč and Lyócsa, 2009). Each Six Sigma project uses a structured and organised approach, led by a project methodology expert and involving a 
team brought together for the purpose of the project (Anand et al, 2009; Margazão, Carvalho, 2015). The same is true for Lean Six Sigma improvement projects (Iyede, Fallon, Donnellan, 2018).

Despite the benefits that such structured approaches can bring, continuous improvement efforts are consistently reported to have high failure rates (McLean, Antony and Dahlgaard, 2017). As these approaches are inextricably linked to projects, success may be defined through successful project management (Laux, Johnson and Cada, 2015). As a result, project performance becomes an important determinant for the successful implementation of continuous improvement initiatives such as Six Sigma (Arumugam, Antony and Linderman, 2014, 2016; Ray et al., 2013). The failure of Six Sigma and Lean Six Sigma projects can undermine the impact of improvement initiatives on business performance (Antony and Gupta, 2019). Bain and Company, a global management consultancy firm conducted a survey on Lean Six Sigma and its benefits in 2008 and reported that $80 \%$ of 184 participating companies claimed that Lean Six Sigma efforts were failing to drive the anticipated value and moreover $74 \%$ claimed that they were not gaining the expected competitive edge as they had not achieved their saving targets from projects (CBIS, 2017). Chakravorty (2010) in his paper which appeared on the Wall Street Journal that an aerospace company which had implemented more than 100 process improvement projects that more than 50 projects had failed to generate lasting gains.

Despite organisational efforts, lean projects have not been consistently successful, often resulting in delay, failure, abandonment or rejection (DeSanctis et al., 2018). In any large-scale Six Sigma deployment comprising several project teams, project team failures are not uncommon (Easton and Rosenzweig, 2012). Kuvvetli, Firuzan, Alpaykut and Gerger (2015) affirm that although successful Six Sigma projects are 
often widely reported in many journals, it is equally important to understand the reasons for their failures.

Although scholars have investigated the critical success factors for the implementation of continuous improvement initiatives (Easton and Rosenzweig, 2012; McLean, Antony and Dahlgaard, 2017; Yadav and Desai, 2017) TQM (e.g., Seetharaman, Sreenivasan and Boon, 2006), Lean (e.g. Netland, 2016), Six Sigma (e.g. Brun, 2011; Kuvvetli et al., 2015) and Lean Six Sigma (e.g., Bakar, Subari and Daril, 2015; Jeyaraman and Teo, 2010), only a few studies have investigated the factors that lead to successful completion of process improvement projects (Arumugan, Antony and Linderman, 2016, Fernandes et al., 2019). From a practical standpoint, successful completion of projects on time and their impact on project performance and subsequently organisational performance cannot be overlooked. Since projects underpin continuous improvement approaches, it is critical to understand the factors that lead to successful project performance (Arumugan, Antony and Linderman, 2014; 2016; Parast, 2011) and identify how we can reduce the risk of failure in continuous improvement projects (Hadi-Vencheh and Yousef, 2017). It is beneficial to observe and analyse from the perspective of project execution, the level of continuous improvement initiatives (Anand et al., 2009; Arumugan, Antony and Linderman, 2016). Most published articles are focused on the critical success factors of the initiative and only a handful number of papers have reported about the key ingredients to make a project successful in any process improvement or continuous improvement initiatives (Antony and Gupta, 2019). This paper focuses on the reasons for failed Six Sigma projects in organisations and the authors argue that this is the first empirical study which makes an attempt to understand the reasons for such failures so that further research can be executed in mitigating the impact of such failures. 
To prevent projects from failing and ending before completion, it is necessary to know the main reasons process improvement project failures. This paper presents the results of a pilot study carried out with manufacturing specialists in Brazil to identify the primary reasons for project failures in process improvement related projects. If the primary reasons for such failures are understood, a framework to mitigate such failures can be developed. The primary contribution of this research lies with understanding and determining the fundamental reasons behind process improvement project failures through an empirical study. The results of this study can be extremely beneficial to senior managers and process improvement champions in organisations to reduce the chances of project failures and have some cash savings to the bottom-line. The next sections address the following topics: Section 2 presents a review of existing literature on the reasons for process improvement project failures; Section 3 covers the research methodology adopted for the study; Section 4 reports the results and key findings of the pilot study followed by discussion of the findings in Section 5. The managerial implications and limitations are highlighted in Section 6 and finally the conclusions and agenda for further research are outlined in Section 7.

\section{Literature Review}

Studies on project failures are imperative as everyone, in general, is associated with various financial and non-financial losses which can impede the development of other potential projects. Additionally, learning from a project failure can play a key role in the planning and monitoring of future projects to ensure the long-term success of any organisation implementing and sustaining continuous improvement initiatives such as Kaizen, Lean, Six Sigma or Lean Six Sigma. 
Graves (2014) reported that many Six Sigma projects fail due to limited number of Six Sigma experts in companies who can work closely with project teams to sustain the project performance over time. He further highlighted the fact that the problem lies with not having the optimal team size for projects as well as lack of motivation for team members from the absence of Six Sigma expert. This finding is quite consistent with our findings of the study which explcitly states that sub-optimal team size could lead to project failure. Moreover, incompetency of team members is also reported to be a potential variable which results in project failure in our findings. Mullavey (2006) presented some of the common reasons for project failures in a typical Six Sigma initiative. He argued that many projects fail because of insufficient resources (time, people) and poor participation among the team members. Intersting enough, this is again found in our findings which suggest that partial coopertaion of employees and their lack of engagement in problem solving scenarios is one of the primary reasons for project failures. The authors would argue that most literature on project failures in process improvement initiatives are written based on the experience of the author with no real evidence with facts or data to back up their findings. The present study explicitly addresses this gap by providing evidence on the reasons for process improvement project failures.

The purpose of this section is to outline the reasons for project failures in any process improvement initiatives such as Lean, Six Sigma or Lean Six Sigma (LSS). However the pilot study was primarily focused on the reasons for Six Sigma projects rather than Lean or LSS projects. The following ten reasons are developed from a research paper published by the first author of this article (Antony and Gupta, 2019).

\subsection{Lack of commitment and support from top management}


The temporary nature of projects typically demands the full commitment from top management, to meet objectives and prevent an extrapolation of project costs and time (Antony and Gupta, 2018). The successful implementation of Six Sigma includes linkages among projects and business objectives, customer needs (Adebanjo et al., 2016) and alignment with strategic goals (Brun, 2011). Regarding alignment, project sponsors and champions have to be supportive and committed to the continuous improvement initiative (Antony and Gupta, 2018). Frequent interaction between the project leader (Green Belts - GB and Black Belts - BB) and top management is encouraged in order to improve project results (Laux, Jonhson, Cada, 2015).

Top management commitment is necessary for project selection, prioritization and progress monitoring and to define and monitor the pace of project improvement (Arumugan, Antony, Kumar, 2013; García-Alcaraz et al., 2018). One of the most important factors in achieving project success is the selection of the 'right' Six Sigma projects (Bilgen and Sen, 2012; Kumar, Antony and Cho, 2009). As a result, top management should review projects regularly to understand project progress and ensure that the project reflects Six Sigma efforts (Laux, Jonhson, Cada, 2015). Essentially, they should lead and monitor Six Sigma projects, provide resources and establish practices for the improvement teams (Laureani and Antony, 2017). This requires top management to be involved in all phases of the project life cycle; from conceptualization (goal setting and project selection), to planning (resource allocation) and implementation (monitoring and control) (Antony and Gupta, 2018).

\subsection{Poor communication practices}

Problems in communication are considered to be one of the primary causes of continuous improvement projects failure (Antony and Gupta, 2018; Tewari, Mittal and Khanduja, 2017). Barriers to communication in the project design and implementation 
phase should be identified as early as possible, as clear communication and clear and shared understanding of the project scope must be in place in order to reduce the chances of project failure (Antony and Gupta, 2018; Gray and Anantatmula, 2009).

(García-Alcaraz et al., 2018) contend that project leaders and project members should use communication and information technologies (Jadhav, Mantha and Rane, 2014; Margazão, Carvalho, 2016) for effective knowledge sharing and for tracking the progress of multi-organizational projects (Antony and Gupta, 2018). Furthermore, the quality of the information (i.e. timeliness, accuracy and usefulness of the information, communication openness and discussion efficiency and effectiveness) is a factor associated with the success of projects (Antony and Gupta, 2018).

To improve communication, Six Sigma project leaders (BB or GB) should be in contact with the project champions on a regular basis to; discuss project progress, receive feedback and promote knowledge and experience transfer (García-Alcaraz et al., 2018). Information can also be reported for champions and sponsors (Antony and Gupta, 2018; Margazão and Carvalho, 2016) who are stakeholders in the projects results.

\subsection{Incompetent teams}

The formation of teams for the execution of process improvement projects is an important factor which can influence the success or failure of projects (Easton and Rosenzweig, 2012). Project team members should have the right skills, knowledge, experience, and abilities to complete the project (Anand et al., 2010; Linderman et al., 2004; Tewari, Mittal and Khanduja, 2017). Different types of experience, such as individual experience, organizational experience, team leader experience, and team familiarity can have differential effects on the likelihood of project success (Easton and Rosenzweig, 2012). 
Although the project leader plays an important role in the performance of the team and consequently of the project (Margazão and Carvalho, 2016; Easton and Rosenzweig, 2012), project performance is a team result (Antony and Gupta, 2018). As such, the team should be equipped with adequate skills, problem-solving expertise, knowledge and motivation to be able to respond to changing business environments (Margazão and Carvalho and, 2016; Antony and Gupta, 2018).

Teamwork involves interdependent tasks and team-level factors such as coordination, cohesiveness, familiarity (experience of working together) (Easton and Rosenzweig, 2012) and team dynamics (Revere, Kadipasaoglu and Zalila 2005), each of which may impact the overall team performance. A team-oriented approach provides the project team with numerous opportunities to share divergent opinions and experiences, which facilitates decisions making based on a growing common and shared understanding of the project goals (Sin, Zailani, Iranmanesh and Ramayah, 2015). As task interdependence increases, it is important to consider the compatibility and cohesiveness between team members to avoid redundancy (Antony and Gupta, 2018).

\subsection{Inadequate training and learning}

The development of Six Sigma projects depends entirely on the training and education which is provided to team members for project execution (Easton and Rosenzweig, 2012; Margazão and Carvalho, 2016; Yadav and Desai, 2017). Training has a positive effect when using Six Sigma methodologies (e.g. DMAIC) to meet project goals and achieve project success ( $\mathrm{Zu}$ and Fredendall, 2009), with problem-solving being key to the learning process (Anand, Ward and Tatikonda, 2010; Arumugan, Antony, Kumar, 2013). Whatever training is provided, the design of its content needs to consider the evolving needs of the project (Antony and Gupta, 2018). As learning is a continual process which needs to be synchronized with any change in the business environment, 
organisations should continually review the links between skills, performance and training programmes (Antony and Gupta, 2018). Training can include widespread basic training as a practice for engaging the workforce and achieving buy-in to improvement initiatives (Laureani and Antony, 2017). Learning at the individual, team and organizational levels is essential for the sustainable deployment of process improvements projects (Antony and Gupta, 2018).

\subsection{Faulty selection of process improvement methodology and its associated tools/techniques}

To guarantee the development of sustainable Lean Six Sigma projects, tools, techniques and methods should be properly used and in the correct order (Iyede, Fallon and Donnellan, 2018) (Antony and Gupta, 2018). The selection of the most appropriate tools from the toolbox as well as the methodologies and resources that best fit the problem are crucial to a good project result (Antony and Gupta, 2018; Henderson and Evans, 2000). Several improvement methodologies have been developed to address a specific type of operational issue that encompasses a set of specific tools (Antony and Gupta, 2018) e.g. DMAIC and the plan-do-check-act cycle (Mast and Lokkerbol, 2012). In the former, the phases are clearly defined with associated supporting tools (Easton and Rosenzweig, 2012), encompassing statistical and non-statistical approaches (Zu, Fredendall and Douglas, 2008). Such supporting tools need time to be correctly implemented (Antony and Gupta, 2018). The DMAIC approach may not be appropriate for ill-structured problems in which subjective perceptions and personal values are deemed important aspects for less extensive problem-solving processes (Mast and Lokkerbol, 2012).

\subsection{Inappropriate rewards and recognition system/culture}


Incentives and rewards are factors that can influence Six Sigma project performance (Arumugam, Antony and Linderman, 2014). The employees should be rewarded for their efforts in Six Sigma projects in order to maintain their interest and motivation (Buch and Tolentino, 2006; García-Alvaraz et al., 2018; Ho, Wang and Chang, 2008). Performance related rewards should be communicated to employees (Buch and Tolentino, 2006) and incentives should be offered in order to increase employee participation and enhance performance-based continuous improvement projects $(\mathrm{Zu}, \mathrm{X}$., et al. 2010). Recognition and reward policies inspire employees to work towards a better outcome in improvement projects (Antony and Gupta, 2018). The incentive or reward system fosters a sense of achievement and company recognition, thus generating greater employee motivation and commitment in future improvement projects, thereby producing a spiral effect (Ho, Wang, Chang, 2008). Rewards and recognition systems also maintain a positive attitude among employees and raise morale, which in turn lead to higher productivity and performance at both individual and organizational levels (Antony and Gupta, 2018).

\subsection{Scope creep}

The major cause of project failure in manufacturing industries includes the inability to define the scope of a project (Antony and Gupta, 2018; Kuvvetli et al., 2016; Tewari, Mittal and Khanduja, 2017). This difficulty has emerged as a Lean Six Sigma barrier in the context of the information technology industry, and may involve a lack of objectives and unclear aspects critical to quality (Shamsi and Alam, 2018). In an uncertain business environment, changes in scope can occur. Scope management techniques should be incorporated at the project planning stage, with any necessary changes occurring through formal control procedures within predetermined time and cost constraints (Antony and Gupta, 2018). Although Six Sigma projects can be scoped and 
defined without an appropriate knowledge of timelines when utilizing basic project management techniques (Laux, Johnson and Cada, 2015), charters or baselines considering time and costs should be based upon previous work (Laux, Johnson, Cada, 2015). Documentation can help to avoid any task duplication and minimize interest conflicts by taking into consideration roles and responsibilities (Antony and Gupta, 2018).

\subsection{Sub-optimal team size and composition}

Team size is an important factor in the conceptualization of a project (Arumugan, Antony and Kumar, 2013; Brun, 2011) and should consider project scope, duration and project complexity (Antony and Gupta, 2018). Organizations should optimize team size with a particular focus on long-term benefits (Antony and Gupta, 2018) and aim not to have too large a project team (Snee, 2010). The composition of a project team is also a critical element for project success (Antony and Gupta, 2018). Employing a crossfunctional team will mitigate project failure as teamwork encourages people with varied skill sets to work together; opposing the silo-mentality (Pinedo-Cuenca, Olalla and Setijono, 2012; Sin et al., 2015). It is also important to ensure that the team has adequate representation from relevant functional units (Antony and Gupta, 2018). Team members should have dedicated time to understand each other's personality for a better team cohesion outcome (Antony and Gupta, 2018; Easton and Rosenzweig, 2012).

Project leaders such as Six Sigma BB (or project sponsors and champions) must hold a facilitator position in the organization in order to ensure management commitment in the allocation of resources (budget and time) for the successful completion of projects (Antony and Gupta, 2018; Hariharan, 2006). Black Belt coaching and mentoring skills and expertise in a Six Sigma project team is positively related to project performance (Antony and Gupta, 2018; Hagen, 2010). The role of Master Black Belts (MBBs) within 
the team is to coach and mentor the $\mathrm{BB}$ and GB who in turn manage individual projects (Antony and Gupta, 2018; Easton and Rosenzweig, 2012).

\subsection{Inconsistent monitoring and control (lack of expert supervision)}

Monitoring and control in project management are important factors for setting the pace for process improvement projects by a process expert (Antony and Gupta, 2018; Arumugan, Antony, Kumar, 2013). Organizations should review projects regularly to understand project progress (García-Alcaraz et al., 2018; Laux, Jonhson, Cada, 2015). Monitoring systems should be designed and developed to track the on-time progress of a project (Antony and Gupta, 2018: Gray and Anantatmula, 2009). Monitoring system reports should be disseminated through the use of visual management tools at workplace seminars and meetings etc. in order to create awareness among team members and for the purpose of corrective actions which may be required (Antony and Gupta, 2018).

\subsection{Resistance to change (partial cooperation by employees)}

The implementation of a Lean Six Sigma project typically involves a change in the existing culture and the acceptance of a new culture for top management and all other employees in the organisation (Antony and Gupta, 2018; Iyede, Fallo and Donnellan, 2018; Yadav and Desai, 2017). Employees can strongly resist change because of unknown consequences, such as job losses, new working practices, new processes and procedures (Antony and Gupta, 2018; Iyede, Fallo and Donnellan, 2018; Kregel and Coners, 2018). As such, it is recommended that management identify potential causes of employees' resistance to change and take appropriate action by developing strategies to sustain a positive culture and avoid this situation in the long-term (Antony and Gupta, 2018). The employees should be included as part of the project ownership, with their 
opinions integrated into each phase of DMAIC thus creating a conducive and collaborative environment, in which employees can learn and be empowered to contribute (Antony and Gupta, 2018; Iyede, Fallo and Donnellan, 2018).

\section{Research Methodology}

Data was collected through an online survey which targeted Six Sigma practitioners and project leaders in various manufacturing organisations including Six Sigma BBs, MBBs, GBs and champions. An online survey method was selected, due to its low cost and the ability to deploy the questionnaire in a standardized way, using selfadministered methods by the respondents (Couper and Miller, 2008). The questionnaire was piloted with five academics, who are experienced in Lean and Six Sigma topics and who have published extensively in peer-reviewed journals, as well as three Lean and Six Sigma practitioners who have significant experience with projects. The purpose of the piloting exercise was to identify those questions which needed improvement from a practical standpoint as well as ensuring that none of the constructs were omitted by the researchers (Forza, 2002).

In order to determine the relative importance of process improvement projects failure factors, opinions were collected from 42 Six Sigma MBBs, BBs, GBs and champions. The sample included professionals who each had experience in improvement projects within a manufacturing industry environment. In sample selection, companies with a history of implementing continuous improvement initiatives such as Lean and Six Sigma were identified. A total of 125 professionals were contacted, and 42 responses were obtained (34\% response rate) which is quite satisfactory for pilot surveys of this nature (Antony and Fergusson, 2004; Antony, 2004). 


\subsection{Survey questionnaire development}

The questionnaire consists of three main parts: respondent background - questions concerning the experience of the respondent and industry sector and size; characterization of the failure rate of improvement projects - questions about the moment of failure and failure rate; and main improvement project failure reasons central questions to the survey objectives. The questions relating to project failure reasons were categorised into ten factors of failure (constructs), with these constructs being further subdivided into variables. The questions were formulated based on the literature presented in Section 2. The structure of part three of the questionnaire, i.e., main constructs and variables are presented in Table 1. A Likert scale of 1-5 (very rarely - very often) was used for the measure variables. Several studies on continuous improvement initiatives also used the Likert scale (e.g. Antony and Fergusson, 2004; Flynn et al., 1990; Hagen, 2010; Netland, 2016, Sin et al., 2015), which is a scale widely used in survey research (Flynn et al., 1990; Hair et al., 2014).

Table 1: Constructs (factor) and variables of process improvement project failure

\begin{tabular}{|l|l|}
\hline \begin{tabular}{l} 
1. Lack of $\begin{array}{l}\text { commitment } \\
\text { and support } \\
\text { from top } \\
\text { management }\end{array}$ \\
\cline { 2 - 2 }
\end{tabular} & $\begin{array}{l}\text { 1.1 Lack of involvement of top management in conceptualization (goal setting and } \\
\text { project selection) }\end{array}$ \\
\cline { 2 - 3 } 1.2 Lack of top management commitment in project planning (resource allocation) \\
\cline { 2 - 3 } and controlling)
\end{tabular}




\begin{tabular}{|c|c|}
\hline \multirow{8}{*}{$\begin{array}{l}\text { 3. Incompetent } \\
\text { team }\end{array}$} & 3.1 Lack of a common goal, and interdependence among team members \\
\hline & 3.2 Lack of adequately skilled team members \\
\hline & 3.3 Lack of problem-solving expertise/knowledge by team members \\
\hline & 3.4 Lack of motivation on behalf of the team members \\
\hline & $\begin{array}{l}\text { 3.5 Lack of establishing and optimizing the project team based on detailed task } \\
\text { descriptions and allocation analysis }\end{array}$ \\
\hline & 3.6 Lack of complementing skill among project members \\
\hline & 3.7 Lack of learning new skills to respond to changes in the business environment \\
\hline & 3.8 Lack of project leadership skills necessary to lead the team \\
\hline \multirow{3}{*}{$\begin{array}{l}\text { 4. Inadequate } \\
\text { training and } \\
\text { learning }\end{array}$} & $\begin{array}{l}\text { 4.1 Lack of strategies that support organic learning between projects through } \\
\text { various training programs and experience-sharing sessions }\end{array}$ \\
\hline & $\begin{array}{l}\text { 4.2 Not taking into account the characteristics of the team members in order to } \\
\text { determine types of training and their content }\end{array}$ \\
\hline & $\begin{array}{l}4.3 \text { The company does not continually review the links between skills, performance, } \\
\text { and training programs }\end{array}$ \\
\hline \multirow{7}{*}{$\begin{array}{l}\text { 5. Faulty } \\
\text { selection of } \\
\text { process } \\
\text { improvement } \\
\text { methodology } \\
\text { and its } \\
\text { associated } \\
\text { tools/techniques }\end{array}$} & 5.1 There is no selection of the methodology that best fits the project problem \\
\hline & 5.2 There is no tool/technique selection process that best fits the project problem \\
\hline & $\begin{array}{l}5.3 \text { There isn't enough time being allocated to data an information collection in } \\
\text { order to deploy tools and techniques effectively }\end{array}$ \\
\hline & 5.4 Tools are applied in the incorrect order \\
\hline & 5.5 There is inadequate time to implement the process improvement methodologies \\
\hline & 5.6 There is overuse of tools and techniques \\
\hline & 5.7 There is underuse of tools and techniques \\
\hline \multirow{2}{*}{$\begin{array}{l}\text { 6. Inappropriate } \\
\text { rewards and } \\
\text { recognition } \\
\text { system/culture }\end{array}$} & 6.1 There is a lack of policies in place to recognize and reward success \\
\hline & $\begin{array}{l}\text { 6.2 There is lack of incentives for project members concerning appropriate } \\
\text { recognition and rewards }\end{array}$ \\
\hline \multirow[t]{3}{*}{ 7. Scope creep } & $\begin{array}{l}\text { 7.1 There is no collaboration between project champions and project leaders } \\
\text { (usually Six Sigma GB or BB) to define the scope of the Project }\end{array}$ \\
\hline & 7.2 There is a lack of scope management techniques in the project planning stage \\
\hline & $\begin{array}{l}\text { 7.3 There is a lack of proper documentation for the scope of the project outlining } \\
\text { the responsibilities of each member }\end{array}$ \\
\hline \multirow{6}{*}{$\begin{array}{l}\text { 8. Sub-optimal } \\
\text { team size and } \\
\text { composition }\end{array}$} & $\begin{array}{l}8.1 \text { Inadequate size of the project team in relation to the scope, duration and } \\
\text { complexity of the projects }\end{array}$ \\
\hline & 8.2 There is no optimization for the team size \\
\hline & $\begin{array}{l}8.3 \text { Lack of enough time to understand the different personalities of each member } \\
\text { for better team cohesion }\end{array}$ \\
\hline & $\begin{array}{l}\text { 8.4 Lack of facilitators with key positions in the organization to ensure management } \\
\text { commitment }\end{array}$ \\
\hline & 8.5 Inadequate representation from relevant functional units in the project team \\
\hline & $\begin{array}{l}\text { 8.6 Lack of participation from MBB in the team as senior coaches with junior } \\
\text { coaches (BB and GB) who manage individual project teams }\end{array}$ \\
\hline \multirow{4}{*}{$\begin{array}{l}\text { 9. Inconsistent } \\
\text { monitoring and } \\
\text { control (lack of } \\
\text { expert } \\
\text { supervision) }\end{array}$} & $\begin{array}{l}\text { 9.1 There is inconsistent monitoring and control of the project processes by a } \\
\text { process expert }\end{array}$ \\
\hline & $\begin{array}{l}\text { 9.2 There is not a permanent process improvement expert who has a reasonable } \\
\text { understanding of the business organization process for consistent monitoring and } \\
\text { control }\end{array}$ \\
\hline & $\begin{array}{l}\text { 9.3 Lack of a monitoring system designed and developed to track the progress of a } \\
\text { project in real-time }\end{array}$ \\
\hline & $\begin{array}{l}\text { 9.4 The output report of the project monitoring is not consistently disseminated } \\
\text { (visual display at the workplace, seminar, meeting, interim report etc.) }\end{array}$ \\
\hline \multirow{5}{*}{$\begin{array}{l}\text { 10. Resistance } \\
\text { to change } \\
\text { (partial } \\
\text { cooperation by } \\
\text { employees) }\end{array}$} & 10.1 Lack of employee participation and involvement in problem solving \\
\hline & $\begin{array}{l}\text { 10.2 The management does not understand the causes of employee's resistance or } \\
\text { underperformance, and does not take immediate action }\end{array}$ \\
\hline & 10.3 There is employee's resistance to change \\
\hline & $\begin{array}{l}10.4 \text { There is no integration of the employees' opinions and cooperation in each } \\
\text { phase of the DMAIC }\end{array}$ \\
\hline & $\begin{array}{l}\text { 10.5 There are no strategies to convince resistant employees to maintain a positive } \\
\text { attitude regarding process improvement projects }\end{array}$ \\
\hline
\end{tabular}




\subsection{Data analysis}

The first part of the study aims to ensure and assess the measurement quality. This is an important factor in analysing measurement errors which are one of the main problems in survey research in the domain of operations management (Bagozzi and Philips, 1991; Forza, 2002). The goodness of measure can be evaluated in terms of reliability (which indicates stability, predictability, accuracy and consistency in measurement) (Forza, 2002; Kerlinger, 1986). The four most common methods to estimate reliability are testretest method, alternative form method, split halves method and the internal consistency method (Forza, 2002). Internal consistency assesses the equivalence, homogeneity and inter-correlation of the items (variables) in a measure (construct). The most widely used reliability indicator in operational management survey research is Cronbach's alpha (Forza, 2002). Therefore, Cronbach's alpha is used to evaluate the measurement quality. Secondly, a descriptive analysis was performed on the data in order to identify the profile of the respondents. Thirdly, the reasons for process improvement projects failures according to the opinion of the survey respondents were identified.

\section{Pilot survey key results}

\subsection{Internal consistency analysis}

Cronbach's alpha was calculated for each construct (see Table 2). It is recommended that for the development of new measures (exploratory studies), a threshold value $>0.6$ is acceptable, while in more advanced stages of research, values $>0.70$ can be regarded as satisfactory (Hair et al. 2014; Nunally and Bernstein, 1994). Values above 0.8 are very reliable in operational management contexts (Forza, 2002). The construct with the lowest value was 0.72 , Therefore, it is fair to conclude that the constructs used in this 
study are reliable, according to Hair et al. (2014), Cronbach (1951) and Nunally and Bernstein (1994).

\subsection{Descriptive analysis}

As can be seen from Figure 1, 60\% of the respondents represent the Chemical, Food and Beverage and Home appliance sectors. As this question was open ended, although mandatory, eight respondents (19\%) identified their sector as manufacturing industry. As it is not possible to identify the specific sector in these cases, they are represented as unclassified.

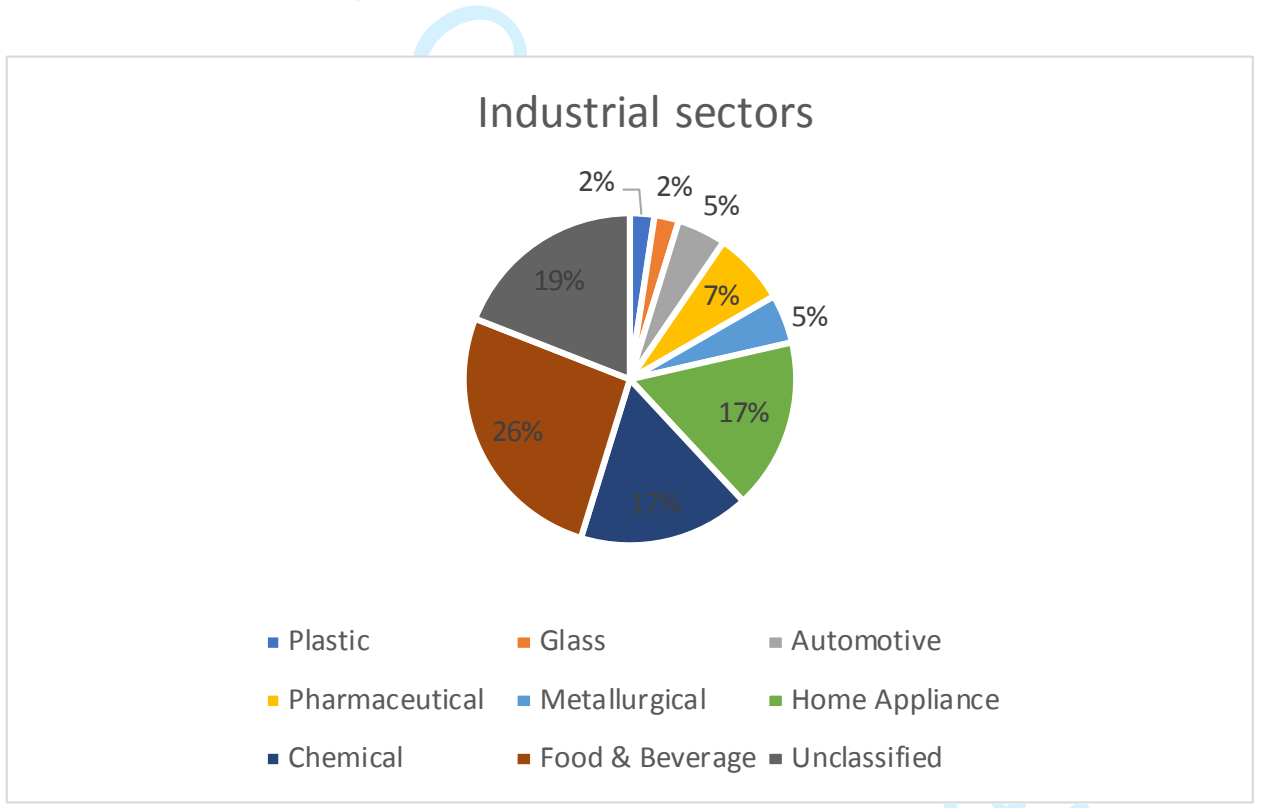

Figure 1: Industrial sectors of the respondents

Figure 2 shows respondents' experience in the execution of continuous improvement projects. $52 \%$ of respondents have greater than 6 year experience in process / continuous improvement projects. $21 \%$ of the respondents have $1-2$ years of experience. No respondent reported less than a year of experience. This result explicitly shows that the data captured from the survey can be very beneficial to this study in identifying and understanding the causes of failure in process improvement projects. 


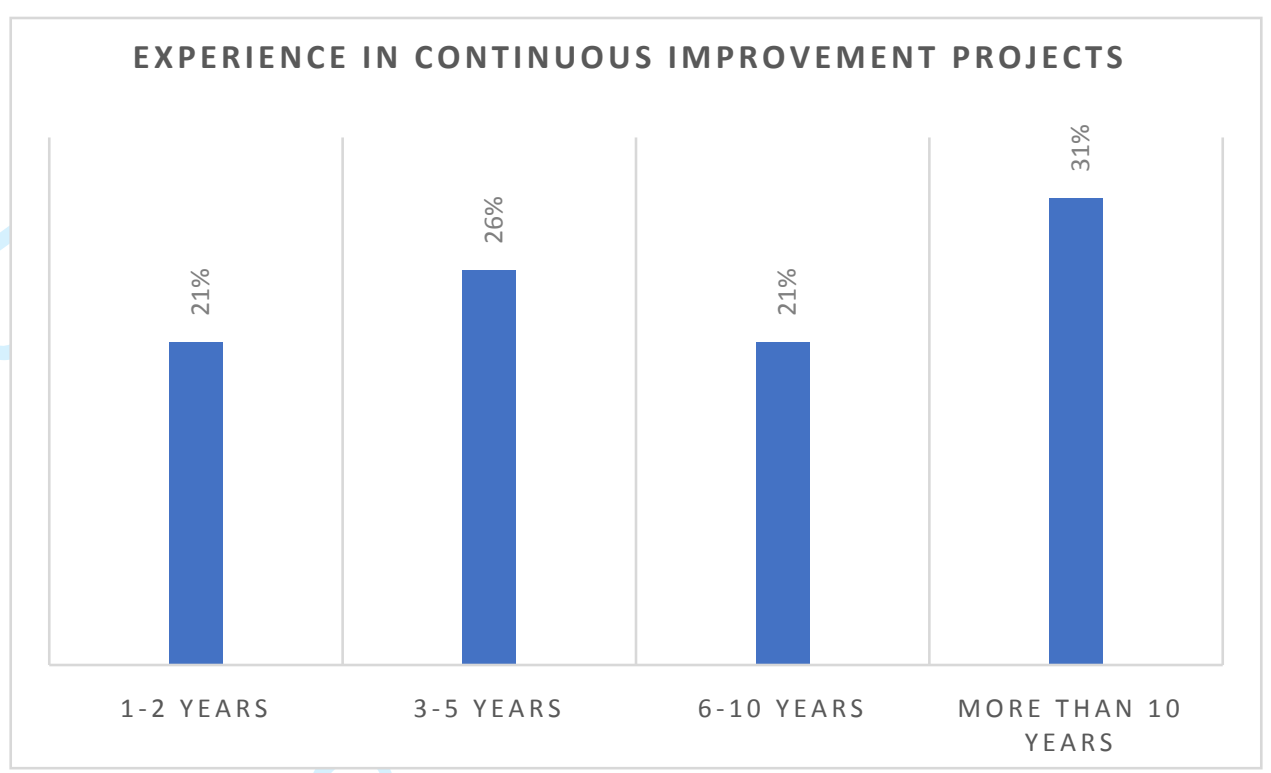

Figure 2: Experience in continuous improvement projects

Figure 3 shows participants' experience in Six Sigma and/or Lean Six Sigma project execution. It can be observed that $48 \%$ of respondents have participated in or completed more than 10 Six Sigma or LSS projects. This demonstrates the wealth of respondent experience with Six Sigma and/or Lean Six Sigma in the execution of process improvement related projects in organisations.

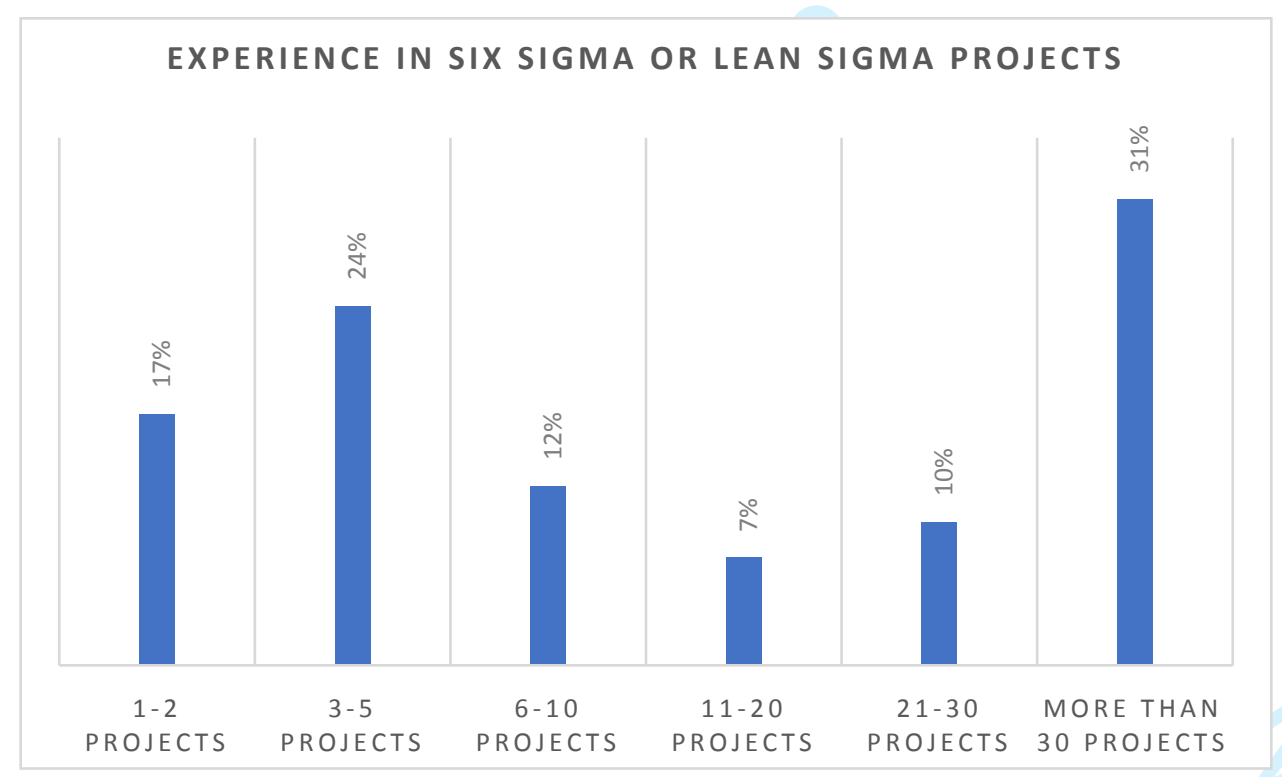

Figure 3: Experience in Six Sigma / Lean Six Sigma projects 
In order to identify the existence of failures in continuous improvement projects, survey participants were asked about project failure rates. Figure 4 shows the failure rates as observed by the experts who worked on the improvement projects. While $23 \%$ of respondents perceive that over $30 \%$ of Six Sigma or Lean Six Sigma projects fail, $24 \%$ of respondents believe that the failure rate is between $11-20 \%$. The figure also highlights that only $14 \%$ of the respondents believe that the failure rate is less than $5 \%$. This indicates that further studies need to be conducted to identify the reasons for project failure.

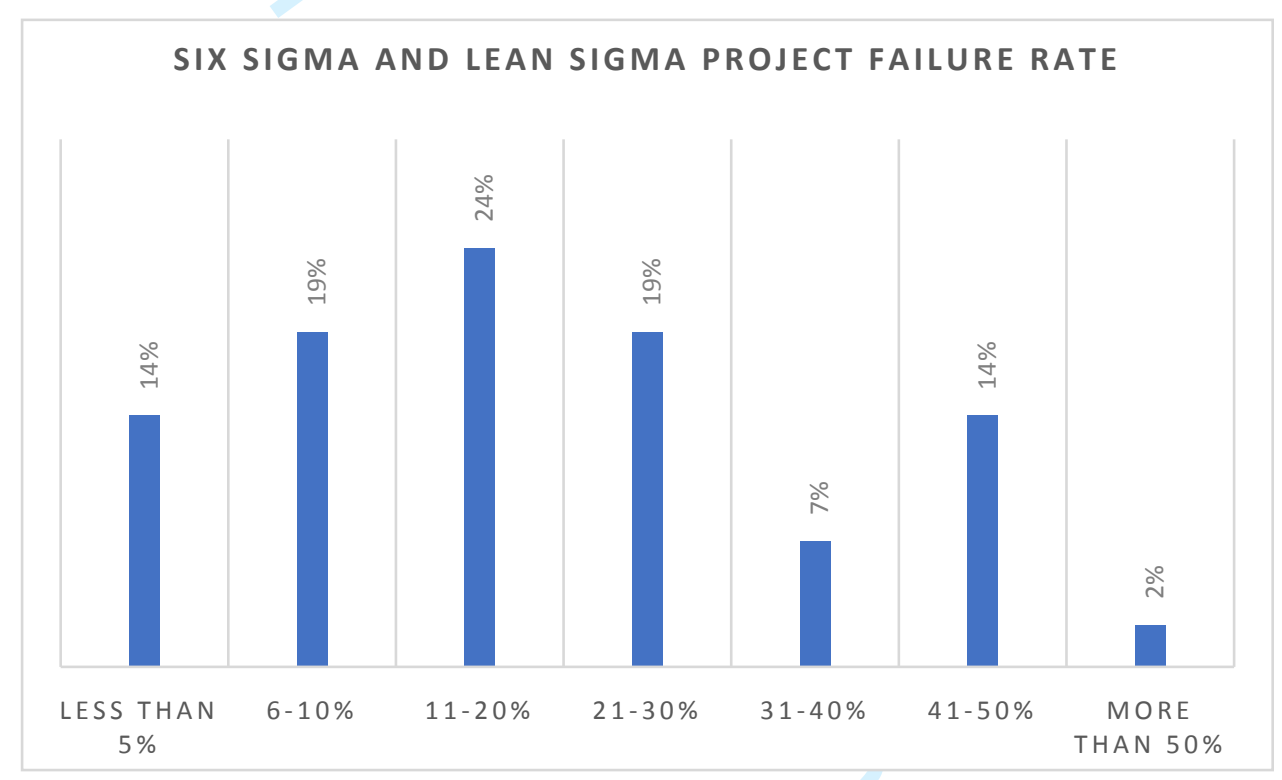

Figure 4: Continuous improvement project failure rate

Participants were questioned about the failure rate at each stage of the improvement cycle (DMAIC), leading to the interruption of the Lean and Lean Six Sigma projects (Figure 5). 
In observing the failure rate whilst considering DMAIC phases, although approximately $50 \%$ of the respondents identified that there are less than $5 \%$ of projects failing in each of the phases, between $24 \%$ and $31 \%$ of respondents consider that failure rate varies between 6-10\%, mainly in the measure, analyse and improve phases. During the analyse phase, $17 \%$ of respondents believe that the failure rate varies between $11-20 \%$. Additionally, $17 \%$ of respondents believe that more than $50 \%$ of projects fail during the control phase, i.e. results are not sustained over time.

The results suggest that project failures occur and that there are particular phases of the DMAIC cycle that are crucial for generating good project results and consequently positive results and support for the improvement initiative. The preliminary results of this pilot study indicate that the measure, analyse, improve and control steps are critical stages to prevent failure which could result in the loss of several thousand dollars or even millions of dollars in matured companies of business process improvement initiatives, depending upon the size of the organisation and the number of Six Sigma projects carried out. 


\subsection{Reasons for failure}

Table 2 shows the average of respondents' opinions in considering the variables that belong to each construct and the standard deviation of the means of the variables that form each construct. Table 2 also highlights that the three main causes of failure of continuous improvement projects are "Resistance to change (partial cooperation by employees)", "Lack of commitment and support from top management" and "Incompetent team". Therefore, the factor that most compromises the improvement projects, as pointed out by the respondents, is associated with the lack of involvement and participation of the employees in solving problems, their resistance to change and a lack of actions to minimize these problems.

Table 2: Main reasons for continuous improvement project failure

\begin{tabular}{lccc}
\hline Failure factors & $\begin{array}{c}\text { Standard } \\
\text { Average }\end{array}$ & $\begin{array}{c}\text { Cronbach's } \\
\text { alpha }\end{array}$ \\
\hline Resistance to change (partial cooperation by employees) & 3.27 & 0.27 & 0.87 \\
Lack of commitment and support from top management & 3.23 & 0.30 & 0.77 \\
Incompetent team & 2.92 & 0.23 & 0.86 \\
Inappropriate rewards and recognition system/culture & 2.89 & 0.01 & 0.96 \\
Inconsistent monitoring and control (lack of expert & & & 0.72 \\
supervision) & 2.89 & 0.03 & 0.83 \\
Inadequate training and learning & 2.83 & 0.15 & 0.82 \\
Sub-optimal team size and composition & 2.80 & 0.33 & 0.88 \\
Poor communication practices & 2.79 & 0.22 & 0.90 \\
Faulty selection of process improvement methodology and & & & 0.87 \\
its associated tools/techniques & 2.68 & 0.28 & 0.14 \\
Scope creep & 2.56 & & \\
\hline
\end{tabular}

Table 3 shows the average of the variables belonging to each construct and indicates how often each of them is responsible for project failures, according to the respondents of the pilot study. The variables with a higher than average value will be observed in more detail as these are the primary ones responsible for process improvement project failures. 
Table 3: Average of the variables

\begin{tabular}{|c|c|c|}
\hline Failure Factors & Variables & Average \\
\hline \multirow{6}{*}{$\begin{array}{lr}\text { 1.Lack } & \text { of } \\
\text { commitment and } \\
\text { support from top } \\
\text { management }\end{array}$} & $\begin{array}{l}\text { 1.1 Lack of involvement of top management in conceptualization (goal } \\
\text { setting and project selection) }\end{array}$ & 3,36 \\
\hline & $\begin{array}{l}\text { 1.2 Lack of top management commitment in project planning (resource } \\
\text { allocation) }\end{array}$ & 3,62 \\
\hline & $\begin{array}{l}\text { 1.3 Lack of top management commitment in project implementation } \\
\text { (monitoring and controlling) }\end{array}$ & 3,45 \\
\hline & $\begin{array}{l}\text { 1.4 Project sponsors (or senior managers) are not committed to } \\
\text { aligning project objectives with the corporate strategy }\end{array}$ & 3,17 \\
\hline & $\begin{array}{l}\text { 1.5 Project champions (or heads of various business functions) are not } \\
\text { committed to aligning project objectives with the corporate strategy }\end{array}$ & 3,12 \\
\hline & $\begin{array}{l}\text { 1.6 Lack of a systematic and transparent methodology for project } \\
\text { selection, prioritization, and project tracking by the management }\end{array}$ & 2,69 \\
\hline \multirow{7}{*}{$\begin{array}{l}\text { 2.Poor } \\
\text { communication } \\
\text { practices }\end{array}$} & $\begin{array}{l}\text { 2.1 Barriers in communication surrounding the project design and } \\
\text { implementation phase }\end{array}$ & 2,64 \\
\hline & $\begin{array}{l}2.2 \text { Lack of development of communication strategies or practices } \\
\text { during the project execution phase }\end{array}$ & 2,74 \\
\hline & 2.3 Lack of communication among the various project stakeholders & 3,14 \\
\hline & $\begin{array}{l}\text { 2.4 Lack of communication about the progress of the project between } \\
\text { the project leaders and the project champions or sponsors }\end{array}$ & 2,76 \\
\hline & $\begin{array}{l}2.5 \text { Poor communication (i.e. timeliness, accuracy and usefulness of } \\
\text { information }\end{array}$ & 2,93 \\
\hline & $\begin{array}{l}\text { 2.6 Poor communication among team members (i.e. communication } \\
\text { openness, discussion efficiency, and discussion effectiveness) }\end{array}$ & 2,90 \\
\hline & $\begin{array}{l}\text { 2.7 Lack of using information and communication technologies for } \\
\text { knowledge sharing across various projects }\end{array}$ & 2,40 \\
\hline \multirow{8}{*}{ 3.Incompetent team } & $\begin{array}{l}\text { 3.1 Lack of a common goal, and interdependence among team } \\
\text { members }\end{array}$ & 2,93 \\
\hline & 3.2 Lack of adequately skilled team members & 3,14 \\
\hline & 3.3 Lack of problem-solving expertise/knowledge by team members & 2,98 \\
\hline & 3.4 Lack of motivation on behalf of the team members & 2,95 \\
\hline & $\begin{array}{l}\text { 3.5 Lack of establishing and optimizing the project team based on } \\
\text { detailed task descriptions and allocation analysis }\end{array}$ & 2,88 \\
\hline & 3.6 Lack of complementing skill among project members & 2,69 \\
\hline & $\begin{array}{l}\text { 3.7 Lack of learning new skills to respond to changes in the business } \\
\text { environment }\end{array}$ & 2,48 \\
\hline & 3.8 Lack of project leadership skills necessary to lead the team & 3,29 \\
\hline \multirow{3}{*}{$\begin{array}{l}\text { 4.Inadequate training } \\
\text { and learning }\end{array}$} & $\begin{array}{l}\text { 4.1 Lack of strategies that support organic learning between projects } \\
\text { through various training programs and experience-sharing sessions }\end{array}$ & 2,62 \\
\hline & $\begin{array}{l}\text { 4.2 Not taking into account the characteristics of the team members in } \\
\text { order to determine types of training and their content }\end{array}$ & 2,98 \\
\hline & $\begin{array}{l}\text { 4.3 The company does not continually review the links between skills, } \\
\text { performance, and training programs }\end{array}$ & 2,90 \\
\hline \multirow{4}{*}{$\begin{array}{l}\text { 5.Faulty selection of } \\
\text { process improvement } \\
\text { methodology and its } \\
\text { associated } \\
\text { tools/techniques }\end{array}$} & $\begin{array}{l}\text { 5.1 There is no selection of the methodology that best fits the project } \\
\text { problem }\end{array}$ & 2,57 \\
\hline & $\begin{array}{l}\text { 5.2 There is no tool/technique selection process that best fits the project } \\
\text { problem }\end{array}$ & 2,62 \\
\hline & $\begin{array}{l}\text { 5.3 There isn't enough time being allocated to data an information } \\
\text { collection in order to deploy tools and techniques effectively }\end{array}$ & 3,21 \\
\hline & 5.4 Tools are applied in the incorrect order & 2,50 \\
\hline
\end{tabular}




\begin{tabular}{|c|c|c|}
\hline & $\begin{array}{l}5.5 \text { There is inadequate time to implement the process improvement } \\
\text { methodologies }\end{array}$ & 2,98 \\
\hline & 5.6 There is overuse of tools and techniques & 2,31 \\
\hline & 5.7 There is underuse of tools and techniques & 2,60 \\
\hline $\begin{array}{l}\text { 6.Inappropriate } \\
\text { rewards and }\end{array}$ & 6.1 There is a lack of policies in place to recognize and reward success & 2,88 \\
\hline $\begin{array}{l}\text { recognition } \\
\text { system/culture }\end{array}$ & $\begin{array}{l}6.2 \text { There is lack of incentives for project members concerning } \\
\text { appropriate recognition and rewards }\end{array}$ & 2,90 \\
\hline & $\begin{array}{l}\text { 7.1 There is no collaboration between project champions and project } \\
\text { leaders (usually Six Sigma GB or BB) to define the scope of the } \\
\text { Project }\end{array}$ & 2,76 \\
\hline 7.Scope cree & $\begin{array}{l}\text { 7.2 There is a lack of scope management techniques in the project } \\
\text { planning stage }\end{array}$ & 2,50 \\
\hline & $\begin{array}{l}7.3 \text { There is a lack of proper documentation for the scope of the project } \\
\text { outlining the responsibilities of each member }\end{array}$ & 2,43 \\
\hline & $\begin{array}{l}8.1 \text { Inadequate size of the project team in relation to the scope, duration } \\
\text { and complexity of the projects }\end{array}$ & 2,40 \\
\hline & 8.2 There is no optimization for the team size & 2,45 \\
\hline & $\begin{array}{l}\text { 8.3 Lack of enough time to understand the different personalities of } \\
\text { each member for better team cohesion }\end{array}$ & 2,81 \\
\hline $\begin{array}{l}\text { 8.Sub-optimal team } \\
\text { size and composition }\end{array}$ & $\begin{array}{l}\text { 8.4 Lack of facilitators with key positions in the organization to ensure } \\
\text { management commitment }\end{array}$ & 3,40 \\
\hline & $\begin{array}{l}8.5 \text { Inadequate representation from relevant functional units in the } \\
\text { project team }\end{array}$ & 2,93 \\
\hline & $\begin{array}{l}\text { 8.6 Lack of participation from MBB in the team as senior coaches with } \\
\text { junior coaches (BB and } \mathrm{GB} \text { ) who manage individual project teams }\end{array}$ & 2,79 \\
\hline & $\begin{array}{l}\text { 9.1 There is inconsistent monitoring and control of the project } \\
\text { processes by a process expert }\end{array}$ & 2,93 \\
\hline $\begin{array}{l}\text { 9.Inconsistent } \\
\text { monitoring and }\end{array}$ & $\begin{array}{l}\text { 9.2 There is not a permanent process improvement expert who has a } \\
\text { reasonable understanding of the business organization process for } \\
\text { consistent monitoring and control }\end{array}$ & 2,90 \\
\hline $\begin{array}{l}\text { control (lack of } \\
\text { expert supervision) }\end{array}$ & $\begin{array}{l}\text { 9.3 Lack of a monitoring system designed and developed to track the } \\
\text { progress of a project in real-time }\end{array}$ & 2,88 \\
\hline & $\begin{array}{l}\text { 9.4 The output report of the project monitoring is not consistently } \\
\text { disseminated (visual display at the workplace, seminar, meeting, } \\
\text { interim report etc.) }\end{array}$ & 2,86 \\
\hline & $\begin{array}{l}\text { 10.1 Lack of employee participation and involvement in problem } \\
\text { solving }\end{array}$ & 3,19 \\
\hline 10.Resistance to & $\begin{array}{l}\text { 10.2 The management does not understand the causes of employee's } \\
\text { resistance or underperformance, and does not take immediate action }\end{array}$ & 3,38 \\
\hline $\begin{array}{lr}\text { change } & \text { (partial } \\
\text { cooperation } & \text { by }\end{array}$ & 10.3 There is employee's resistance to change & 3,67 \\
\hline $\begin{array}{l}\text { cooperation } \quad \text { b } \\
\text { employees) }\end{array}$ & $\begin{array}{l}\text { 10.4 There is no integration of the employees' opinions and } \\
\text { cooperation in each phase of the DMAIC }\end{array}$ & 2,83 \\
\hline & $\begin{array}{l}\text { 10.5 There are no strategies to convince resistant employees to } \\
\text { maintain a positive attitude regarding process improvement projects }\end{array}$ & \\
\hline
\end{tabular}


As a more direct observation, Table 4 shows the ten variables having the highest averages and, consequently, can be identified as the main causes for the failure of improvement projects. Four of the variables are related to the "resistance to change" factor, being resistance to change, the understanding of the causes of employee's resistance and mitigation action by management, strategies to convince resistant employees to maintain a positive attitude and the lack of employee participation in problem solving. The second factor with the most variables identified as frequent for failure is the commitment of top management, the three variables are a lack of top management commitment in project planning (resource allocation), project implementation (monitoring and controlling) and in conceptualization (goal setting and project selection). Therefore, the most highlighted practices relating to top management commitment are linked to the execution of projects (from selection to monitoring).

Table 4: The main variables pointed as causes of project failures

\begin{tabular}{|c|c|c|}
\hline Construct (factor) & Variables & Average \\
\hline $\begin{array}{l}\text { Resistance to change (partial } \\
\text { cooperation by employees) }\end{array}$ & 10.3 There is employee's resistance to change & 3.67 \\
\hline $\begin{array}{l}\text { Lack of commitment and support } \\
\text { from top management }\end{array}$ & $\begin{array}{l}\text { 1.2 Lack of top management commitment in project } \\
\text { planning (resource allocation) }\end{array}$ & 3.62 \\
\hline $\begin{array}{l}\text { Lack of commitment and support } \\
\text { from top management }\end{array}$ & $\begin{array}{l}\text { 1.3 Lack of top management commitment in project } \\
\text { implementation (monitoring and controlling) }\end{array}$ & 3.45 \\
\hline $\begin{array}{l}\text { Sub-optimal team size and } \\
\text { composition }\end{array}$ & $\begin{array}{l}\text { 8.4 Lack of facilitators with key positions in the } \\
\text { organization to ensure management commitment }\end{array}$ & 3.40 \\
\hline $\begin{array}{l}\text { Resistance to change (partial } \\
\text { cooperation by employees) }\end{array}$ & $\begin{array}{l}\text { 10.2 The management does not understand the causes } \\
\text { of employee's resistance or underperformance, and } \\
\text { does not take immediate action }\end{array}$ & 3.38 \\
\hline $\begin{array}{l}\text { Lack of commitment and support } \\
\text { from top management }\end{array}$ & $\begin{array}{l}\text { 1.1 Lack of involvement of top management in } \\
\text { conceptualization (goal setting and project selection) }\end{array}$ & 3.36 \\
\hline Incompetent team & $\begin{array}{l}\text { 3.8 Lack of project leadership skills necessary to lead } \\
\text { the team }\end{array}$ & \\
\hline $\begin{array}{l}\text { Resistance to change (partial } \\
\text { cooperation by employees) }\end{array}$ & $\begin{array}{l}\text { 10.5 There are no strategies to convince resistant } \\
\text { employees to maintain a positive attitude regarding } \\
\text { process improvement projects }\end{array}$ & \\
\hline $\begin{array}{l}\text { Faulty selection of process } \\
\text { improvement methodology and } \\
\text { its associated tools/techniques }\end{array}$ & $\begin{array}{l}\text { 5.3 There isn't enough time being allocated to data an } \\
\text { information collection in order to deploy tools and } \\
\text { techniques effectively }\end{array}$ & \\
\hline $\begin{array}{l}\text { Resistance to change (partial } \\
\text { cooperation by employees) }\end{array}$ & $\begin{array}{l}\text { 10.1 Lack of employee participation and involvement } \\
\text { in problem solving }\end{array}$ & \\
\hline
\end{tabular}


Three factors have only one variable among the ten with the highest mean. One factor is "Incompetent team", and the variable "Lack of project leadership skills necessary to lead the team", shows the importance of this variable for the third highest average factor. Another important variable for failure is "Lack of facilitators with key positions in the organization to ensure management commitment", which indicates that the projects as well as the improvement initiatives are dependent on the organization's structure and its support for project implementation. Another variable highlighted refers to the methodology and tools and, despite its difficulty of use, this variable was not the most important reason for this construct, but rather the lack of time to effectively enforce the methodology and tools. This time constraint may compromise the improvement project analysis phase and the subsequent phases of the DMAIC cycle.

\section{Discussion}

The reasons provided for continuous improvement projects failure are not well explored in the literature and are limited in terms of empirical studies (Arumugan, Antony and Linderman, 2016). The continuous improvement approaches, such as Lean, Six Sigma and Lean Six Sigma are directly related to the execution of projects and success may be defined through successful project management (Laux, Johnson and Cada, 2015). Therefore, this study aims to contribute to filling this literature gap, especially since there are direct managerial implications in practitioners' awareness of the reasons for process improvement project failures. We identify and describe ten factors that can influence the failure of process improvement projects based on the literature. These factors were then investigated empirically through an online pilot survey, completed by specialists who had experience in process improvement projects in manufacturing organizations. 
The findings of the study suggest that improvement projects have a moderate failure rate in manufacturing companies and moreover the failure rate is most common in the measure, analyse, improve and control phases of the Six Sigma problem solving methodology. This finding was a big surprise to the authors as practitioners of Six Sigma and Lean Six Sigma and moreover a few studies have reported that the "Define Phase" in the Six Sigma problem solving methodology is a very critical phase (Pyzdek and Keller, 2018; Voehl et al., 2014). One of the biggest concerns for many project leaders and Six Sigma practitioners is that the improved performance for many projects could not be sustained over time in the control phase which potentially implies significant resource (i.e., time in particular) loss and increased cost. The failures within the control phase indicate that the results are not sustained and this may destabilize the overall improvement approach, causing the organization to give up on the continuous improvement initiative (Snee and Hoerl, 2018; Antony et al, 2018).

The main findings of the study involve the identification of the construct and highlighted the main reason for failure as resistance to change (partial cooperation by employees). Although this finding has been identified in many books and articles, it was never empirically proven with data collated from practitioners of Six Sigma. Albliwi et al. (2014) reported the critical failure factors of Lean Six Sigma and one of the factors identified in their systematic review was resistance to change across the middle management level. McLean and Antony (2014) also highlighted the importance of resistance to change at the organisational level in their study on the failure of continuous improvement initiatives such as Lean and Six Sigma. The main variables of this failure are; resistance to change by employees, lack of employee involvement in problem solving, and lack of understanding, actions and strategies by management to convince resistant employees to maintain a positive attitude. This suggests that one of 
the main reasons for failure involves a change in culture, moving towards a culture of improvement in which people understand the importance of and are willing to contribute to improvement projects. Culture shift is a challenging task for managers.

Top management is also a critical factor for failure, and as already pointed out as a prominent factor of success (Netland, 2016; Brun, 2011), the lack of direct commitment in the projects leads to the failure and the waste of resources. Management plays a crucial role in monitoring projects, from the selection and application of resources to post-implementation and sustainability of results. Top management can also play a role regarding the resistance to change and senior managers should understand the reasons and develop remedial actions to mitigate the causes of resistance.

The team also compromises on project success, where it is necessary to develop the team members' skills, including problem-solving. The composition of the team can be construed as a barrier, as the team ideally should be chosen for the specific project purpose and members' skills should be complementary. Snee and Hoerl (2018) emphasise the importance of team formation in the execution of Six Sigma Black Belt and Green Belt projects. The best approach to forming the team is to create it in consultation with the Six Sigma project champion and the managers to whom the prospective team members report the progress of the projects. Inappropriate rewards and recognition systems can also compromise the development of the project by not motivating the members to execute it. Additionally, the reward system may cause employees, who are not part of the Belt hierarchy, to feel underappreciated and they can misinterpret the progress of the project due to a lack of data and/or information, and perhaps also perceived barriers to the realization of projects. Inconsistent monitoring and control is also a factor for failure and is related to the most troubling stage of 
DMAIC for project failure, which is the control step. McLean and Antony (2014) highlighted in their research that one of the failure factors for implementation of Lean and Six Sigma is the lack of feedback and lack of effective monitor and control in the entire project life cycle.

\section{Managerial /Practical implications and Limitations}

This research has some important implications for managers; process improvement projects leaders and process improvement project members in all organisations. The findings suggest that failure in improvement projects cannot be ignored as the cost to organisations may include the loss of significant resources in terms of time and manpower. This implies that it is vital for senior managers and project leaders such as Six Sigma MBBs and BBs to identify and understand those factors which cause process improvement project failures so that remedial measures can be taken to mitigate against the impact of these failures. Moreover, continuous improvement or process improvement champions play an immense role in the project selection and completion of projects led by Six Sigma MBBs/BBs/GBs. The awareness of reasons for failures at the project level, team level and organisational level for such champions can be very beneficial to reduce the chances of failures which result in significant cash, time and energy loses by several individuals who play a role in project execution. This paper illustrates the main causes of failures which occur when process improvement project leaders execute projects at strategic and operational levels. The role of senior managers and process improvement project leaders play in reducing the chances of project failures are also highlighted.

As with any research, this study has some limitations. First and foremost, this was a pilot study with a relatively limited number of process improvement projects. Due to the limited sample size, a more advanced statistical analysis on the data was not 
performed and therefore the findings could not be generalised. As the study comprised of several variables for each factor, these were not explored further in the study. However, multivariate studies for greater understanding of the most important variables and their relationship with other variables could be performed with a larger number of respondents. Most of the data collection was from Brazilian companies and it would be worthwhile exploring the causes of failures related to process improvement projects in other cultural contexts (i.e., Europe, North America and Asia). Moreover, the authors would like to understand the organisational culture (via country culture) and its impact on the success and failure of process improvement projects. The leadership in various cultural contexts should also be taken into account during such investigations. Also, samples were taken from manufacturing companies and it would be interesting to evaluate the causes of failures in service organisations and to understand if any perceived differences in causes of failures exist between the manufacturing and service companies. The authors also could not explore the correlation between the experiences of a project leader who is actively involved in the execution of process improvement projects and the success and failure rate of projects. Our hypothesis could be “experienced process improvement project leaders would have a better project success rate than inexperienced project leaders".

Finally, the authors would like to emphasise the point that surveys are not good enough to get deeper and accurate insights into the project failures. In such circumstances, the next stage of the research is to collate data from a series of semi-structured interviews with a number of project leaders and champions who have been involved in the project selection and execution in various sectors. The results from a mixed approach (i.e., qualitative and quantitative) would be the way forward for the development of a strategic and practical framework/model to mitigate project failures. The authors will 
also be looking into development of a mathematical model linking project failure and the most contributing variables so that failures can be predicted for various types of projects with some degree of confidence or power through more data collection exercises in the future.

\section{Conclusions and Agenda for further research}

Improvement initiatives such as Six Sigma and Lean Six Sigma are increasingly widespread in manufacturing companies and other types of organizations, but there is still a high drop-out rate for companies, mainly due to the high costs and absence of results. Project failure, occurs when there is no return on investment or time invested which can undermine interest and efforts required for any process improvement initiative. This paper reports on the results of a Six Sigma pilot survey carried out with Brazilian continuous improvement specialists from manufacturing companies. The results of the study showed that there is a moderate rate of project failures and that one of the most worrisome stages is control, the stage where projects are discontinued, and results are not maintained. This could cost organisations several thousands of dollars or in some bigger multi-national corporations this could be several multi-million dollars. The paper also presents the factors and variables which identify the main reasons for failure. This study was carried out with some limitations such as the sample size (pilot study) and a focus on Brazilian companies and specialists with manufacturing experience. Due to limited sample size of the study, the authors could not perform any advanced statistical analyses (e.g.: factor analysis). Moreover, the authors did not carry out a separate analysis with different sizes of the firms participated in the pilot survey to determine if the firm size has any impact on failure rate of process improvement projects. Moreover no analysis has been performed to understand if companies with 
high degree of maturity on Six Sigma implementation have less impact on project failure rates or not.

The next step of this research is to expand the survey to other countries and later, to other types of companies, trying not only to identify the factors and variables of failure, but also to perform, through statistical analysis, the relationship between the factors and to identify the ones that are most critical to failure. Also, future steps will include an investigation to mitigate against project failures, according to specialists, top management and others. Moreover, the authors would like to further explore if there are any perceived differences in project failure rates between manufacturing and service firms who have adopted process improvement methodologies such as Lean and Six Sigma. 


\section{References}

Adebanjo, D., Samaranayake, P., Mafakheri, F., \& Laosirihongthong, T. (2016). Prioritization of six-sigma project selection: a resource-based view and institutional norms perspective. Benchmarking: An International Journal, 23(7), 1983-2003.

Albliwi, S. Antony, J. and van der Wiele, T. (2014) "Critical failure factors of Lean Six Sigma: a systematic literature review", International Journal of Quality \& Reliability Management, Vol. 31 Issue: 9, pp.1012-1030

Anand, G., Ward, P. T., \& Tatikonda, M. V. (2010). Role of explicit and tacit knowledge in Six Sigma projects: An empirical examination of differential project success. Journal of Operations Management, 28(4), 303-315.

Antony, J. (2004). Six Sigma in the UK service organisations: results from a pilot survey. Managerial Auditing Journal, 19(8), 1006-1013.

Antony, J., \& Fergusson, C. (2004). Six Sigma in the software industry: results from a pilot study. Managerial Auditing Journal, 19(8), 1025-1032.

Antony, J., Gupta, S., Sunder M., V. and Gijo, E.V. (2018) "Ten Commandments of Lean Six Sigma: a practitioners' perspective", International Journal of Productivity and Performance Management, Vol. 67 Issue: 6, pp.1033-1044.

Antony, J., \& Gupta, S. (2019). Top ten reasons for process improvement project failures. International Journal of Lean Six Sigma, Vol10, No.1, pp. 367-374.

Arumugam, V., Antony, J., \& Kumar, M. (2013). Linking learning and knowledge creation to project success in Six Sigma projects: An empirical investigation. International Journal of Production Economics, 141(1), 388-402.

Arumugam, V., Antony, J., \& Linderman, K. (2014). A multilevel framework of Six Sigma: A systematic review of the literature, possible extensions, and future research. Quality Management Journal, 21(4), 36-61.

Arumugam, V., Antony, J., \& Linderman, K. (2016). The influence of challenging goals and structured method on Six Sigma project performance: A mediated moderation analysis. European Journal of Operational Research, 254(1), 202-213.

Bagozzi, R. P., Yi, Y., \& Phillips, L. W. (1991). Assessing construct validity in organizational research. Administrative science quarterly, 421-458.

Bakar, F. A., Subari, K., \& Daril, M. A. (2015). Critical success factors of Lean Six Sigma deployment: a current review. International Journal of Lean Six Sigma, 6(4), 339-348.

Bilgen, B., \& Şen, M. (2012). Project selection through fuzzy analytic hierarchy process and a case study on Six Sigma implementation in an automotive industry. Production Planning \& Control, 23(1), 2-25.

Brun, A. (2011). Critical success factors of Six Sigma implementations in Italian companies. International Journal of Production Economics, 131(1), 158-164. 
Buch, K., \& Tolentino, A. (2006). Employee perceptions of the rewards associated with six sigma. Journal of Organizational Change Management, 19(3), 356-364.

Chakravorty, S. S. (2010). Where process-improvement projects go wrong. Wall Street Journal, No.19, p. 255.

Comprehensive Business Improvement Solutions or CIBS (2017), http://www.cbisco.com.au/top-10-reasons-lean-six-sigma-projects-fails (accessed on 26th March 2019).

Couper, M. P., \& Miller, P. V. (2008). Web survey methods: Introduction. Public Opinion Quarterly, 72(5), 831-835.

Cronbach, L. J. (1951). Coefficient alpha and the internal structure of tests. Psychometrika, 16(3), 297-334.

DeSanctis, I., Mere, J. B. O., Bevilacqua, M., \& Ciarapica, F. E. (2018). The moderating effects of corporate and national factors on lean projects barriers: a cross-national study. Production Planning \& Control, 29(12), 972-991.

Easton, G. S., \& Rosenzweig, E. D. (2012). The role of experience in six sigma project success: An empirical analysis of improvement projects. Journal of Operations Management, 30(7-8), 481-493.

Fernandes, M.M. et al. (2019), 18 steps to Six Sigma Project Success, Quality Progress, February, pp. 17-23.

Forza, C. (2002). Survey research in operations management: a process-based perspective. International journal of operations \& production management, 22(2), 152194.

Flynn, B. B., Sakakibara, S., Schroeder, R. G., Bates, K. A., \& Flynn, E. J. (1990). Empirical research methods in operations management. Journal of operations management, 9(2), 250-284.

García-Alcaraz, J., Alor-Hernández, G., Sánchez-Ramírez, C., Jiménez-Macías, E., Blanco-Fernández, J., \& Latorre-Biel, J. (2018). Mediating Role of the Six Sigma Implementation Strategy and Investment in Human Resources in Economic Success and Sustainability. Sustainability, 10(6), 1828.

Gray, J., \& Anantatmula, V. (2009). Managing Six Sigma projects through the integration of Six Sigma and project management processes. International journal of six sigma and competitive advantage, 5(2), 127-143.

Graves, A. (2014), Avoiding a Six Sigma Project Failure, Six Sigma Daily, May, pp. 15 (http://www.sixsigmadaily.com/avoiding-failed-six -sigma-projects/).

Hadi-Vencheh, A., \& Yousefi, A. (2018). Selecting Six Sigma project: a comparative study of DEA and LDA techniques. International Journal of Lean Six Sigma, 9(4), 506522.

Hagen, M. (2010). Black belt coaching and project outcomes: An empirical investigation. Quality Management Journal, 17(2), 54-67. 
Hair, J. F., G. Tomas, M. Hult, Christian M. Ringle, and M. Sarstedt. (2014). A Primer on Partial Least Squares Structural Equation Modeling (PLS-SEM). Sage, Thousand Oaks, CA.

Hariharan, A. (2006). CEO's guide to Six Sigma success.

Henderson, K. M., \& Evans, J. R. (2000). Successful implementation of Six Sigma:

benchmarking general electric company. Benchmarking: An International Journal, 7(4), 260-282.

Ho, Y. C., Chang, O. C., \& Wang, W. B. (2008). An empirical study of key success factors for Six Sigma Green Belt projects at an Asian MRO company. Journal of Air Transport Management, 14(5), 263-269.

Iyede, R., Fallon, E. F., \& Donnellan, P. (2018). An exploration of the extent of Lean Six Sigma implementation in the West of Ireland. International Journal of Lean Six Sigma, 9(3), 444-462.

Jadhav, J. R., Mantha, S., \& Rane, S. B. (2014). Exploring barriers in lean implementation. International Journal of Lean Six Sigma, 5(2), 122-148.

Jeyaraman, K., \& Teo, L.K. (2010). A conceptual framework for critical success factors of lean Six Sigma: Implementation on the performance of electronic manufacturing service industry. International Journal of Lean Six Sigma, 1(3), 191-215.

Kerlinger, F.N (1986), Foundations of behaviour research, $3^{\text {rd }}$ ed, New York: Harcourt Brace JovanovichCollege Publisher.

Kregel, I., \& Coners, A. (2018). Introducing Lean Six Sigma to a German municipality: an action research report. International Journal of Lean Six Sigma, 9(2), 221-237.

Kumar, M., Antony, J., \& Cho, B. R. (2009). Project selection and its impact on the successful deployment of Six Sigma. Business Process Management Journal, 15(5), 669-686.

Kuvvetli, Ü., Firuzan, A. R., Alpaykut, S., \& Gerger, A. (2016). Determining Six Sigma success factors in Turkey by using structural equation modeling. Journal of Applied Statistics, 43(4), 738-753.

Laureani, A., \& Antony, J. (2017). Leadership characteristics for lean six sigma. Total Quality Management \& Business Excellence, 28(3-4), 405-426.

Laux, C., Johnson, M., \& Cada, P. (2015). Project barriers to Green Belts through critical success factors. International Journal of Lean Six Sigma, 6(2), 138-160.

Linderman, K., Schroeder, R. G., Zaheer, S., Liedtke, C., \& Choo, A. S. (2004). Integrating quality management practices with knowledge creation processes. Journal of Operations Management, 22(6), 589-607.

Marzagão, D. S. L., \& Carvalho, M. M. (2016). Critical success factors for Six Sigma projects. International Journal of Project Management, 34(8), 1505-1518. 
Mast, J., \& Lokkerbol, J. (2012). An analysis of the Six Sigma DMAIC method from the perspective of problem solving. International Journal of Production Economics, 139(2), 604-614.

Mclean, R.S. and Antony, J. (2014), "Why continuous improvement initiatives fail in manufacturing environments? A systematic review of the evidence", International Journal of Productivity and Performance Management, Vol. 63 Issue: 3, pp.370-376

McLean, R. S., Antony, J., \& Dahlgaard, J. J. (2017), Failure of continuous improvement initiatives in manufacturing environments: a systematic review of the evidence. Total Quality Management \& Business Excellence, 28(3-4), 219-237

Mullavey, F. (2006), Shackled by Bad Six Sigma?, Quality Digest, January, pp. 1-3.

Netland, T. H. (2016). Critical success factors for implementing lean production: the effect of contingencies. International Journal of Production Research, 54(8), 24332448 .

Nunally, J. C., \& Bernstein, I. (1994). Psychometric theory. New York: McGraw-Hill.

Parast, M. M. (2011). The effect of Six Sigma projects on innovation and firm performance. International Journal of Project Management, 29(1), 45-55.

Pinedo-Cuenca, R., Olalla, P. G., \& Setijono, D. (2012). Linking Six Sigma's critical success/hindering factors and organizational change (development) A framework and a pilot study. International Journal of Lean Six Sigma, 3(4), 284-298.

Pyzdek, T. and Keller, P. (2018), The Six Sigma Handbook, $5^{\text {th }}$ Edition, McGraw-Hill Publishers, Ney York, USA.

Ray, S., Das, P., Bhattacharyay, B. K., \& Antony, J. (2013). Measuring Six Sigma project effectiveness using fuzzy approach. Quality and Reliability Engineering International, 29(3), 417-430.

Revere, L., Kadipasaoglu, S. N., \& Zalila, F. (2005). An empirical investigation into Six Sigma critical success factors. International Journal of Productivity and Quality Management, 1(3), 224-252.

Seetharaman, A., Sreenivasan, J., \& Boon, L. P. (2006). Critical success factors of total quality management. Quality and quantity, 40(5), 675-695.

Shamsi, M. A., \& Alam, A. (2018). Exploring Lean Six Sigma implementation barriers in Information Technology industry. International Journal of Lean Six Sigma, 9(4), $523-542$.

Sin, A. B., Zailani, S., Iranmanesh, M., \& Ramayah, T. (2015). Structural equation modelling on knowledge creation in Six Sigma DMAIC project and its impact on organizational performance. International Journal of Production Economics, 168, 105117.

Snee, R. D. (2010). Lean Six Sigma-getting better all the time. International Journal of Lean Six Sigma, 1(1), 9-29. 
Snee, R. and Hoerl, R. (2018), Leading Holistic Improvement with Lean Six Sigma 2.0, Second Edition, Pearson Education, Canada.

Stelson, P., Hille, J., Eseonu, C., \& Doolen, T. (2017). What drives continuous improvement project success in healthcare?. International journal of health care quality assurance, 30(1), 43-57.

Tkáč, M., \& Lyócsa, Š. (2010). On the evaluation of Six Sigma projects. Quality and reliability engineering international, 26(1), 115-124.

Tewari, P. C., Mittal, K., \& Khanduja, D. (2017). On the right approach to selecting a quality improvement project in manufacturing industries. Operations Research and Decisions, 27(1), 105-124.

Voehl, F. et al. (2014), The Lean Six Sigma Black Belt Handbook - Tools and methods for Process Acceleration, CRC Press, Florida, USA

Wackerbarth, S. B., Strawser-Srinath, J. R., \& Conigliaro, J. C. (2015). The human side of lean teams. American Journal of Medical Quality, 30(3), 248-254.

Yadav, G., \& Desai, T. N. (2017). A fuzzy AHP approach to prioritize the barriers of integrated Lean Six Sigma. International Journal of Quality \& Reliability Management, 34(8), 1167-1185.

Zu, X., \& Fredendall, L. D. (2009). Enhancing Six Sigma implementation through human resource management. Quality Management Journal, 16(4), 41-54.

Zu, X., Fredendall, L. D., \& Douglas, T. J. (2008). The evolving theory of quality management: the role of Six Sigma. Journal of operations Management, 26(5), 630650 .

Zu, X., Robbins, T.L. and Fredendall, L.D., 2010. Mapping the critical links between organizational culture and TQM/Six Sigma practices. International journal of production economics, 123(1), pp.86-106. 